\title{
JOURNAL OF CORPORATE RESPONSIBILITY
}

AND LEADERSHIP

Human Resources

\& Diversity Management

\section{Searching for a Perfect Composition for a Board of Directors}

DOI: http://dx.doi.org/10.12775/JCRL.2017.002

\author{
JOANNA HERNIK \\ The Faculty of Economics, \\ West Pomeranian University of Technology in Szczecin, Poland \\ e-mail: jhernik@zut.edu.pl
}

\section{Antonio Minguez Vera}

The Faculty of Economics and Business,

The University of Murcia, Spain

e-mail: minver@uma.es

\begin{abstract}
Background: When one hears that company X achieved success, adopted a strategy, or struggles with difficulties, there is always a company board behind this news. Typically, a company board is a reflection of decisions taken by the owner; in practice, there is no rule as to how to appoint a company board. However, if we consider the long-term interest of the company, we may suggest a few ideas that will allow the company to better adapt to the market; they may also help to build the competitive advantage and have a positive impact on the company's market position. This article presents a belief that the company board composition should evolve from merely reflecting the goals of the owner and the professionalism of the members, into a board, whose structure reflects employees and the market in which the company operates. This approach stems from the need to adapt to the market conditions, which is easier when the process of change starts with the company board. To illustrate these ideas, a fictitious example of a limited liability company will be used, for which we developed various board models based on the market situation
\end{abstract}


Purpose: The aim of this article is to develop a new approach to board of directors' creation, through the lens of decision-making theory, sustainable development and business performance.

Design / methodology / approach: To build a new model of a board of directors, a critical-realistic approach was used along with a case study of a fictitious limited liability company. Hypothetical-deductive technique was a base of the analysis.

Findings: Conceptual models of a board of directors - which reflected human capital of the company and market structure were developed.

Research and practical limitations/implications: A guidance for businesspeople on how to compose a board of directors is provided. As this is a theoretical work, it may be a base for future market/ real testing of the presented ideas.

Originality/value: The article responds to a lack of research and wider works on connections between a board of directors and developing company performance, so this paper will be of particular value to those involved in the appointment of directors. In conclusions, we propose how to create better boards of directors.

Paper type: Conceptual article.

Keywords: board of directors, changes, corporate governance, human resources, market.

\section{Introduction}

Leadership and management are the key elements which condition current and future situation of an entity on the market. Both are associated with operations of the board, which is a specific organ of the company, one that implements best solutions for the company. 'Management' is understood as the use and coordination of resources - such as capital, tangible assets and work - to achieve certain objectives (Sudoł, 2007, p. 23); management usually includes: planning, organising, motivating and controlling.

The first of the above-mentioned activities (management functions) - i.e. planning - involves predicting future conditions, as well as determining the means by which objectives will be achieved. 'Organising' means a structured selection of means and operating conditions, which result in a certain structure. Motivating employees (i.e. performers of tasks) is aimed at stimulating their activity to effectively obtain company objectives. Controlling - the last management function involves periodic or final evaluation of actions and comparison with 
the original plan (Dołhasz, Fudaliński, Kosala and Smutek, 2009, pp. 48-53).

Similarly, we may analyse functions (tasks) of company boards. According to Boland and Hofstrand (2009), the main tasks of boards may be summarized in six points:

(1) developing vision, mission and goals for the company;

(2) determining the governance system;

(3) hiring, supervision, retention, evaluation and rewarding company managers;

(4) management of the organisation in collaboration with the CEO;

(5) protection of the invested funds and property of the owners, for their benefit;

(6) monitoring and controlling the company - personally or by an auditor.

One may certainly say that the tasks of every board also include: planning, organising, motivating and controlling what is happening in the company (Figure 1).

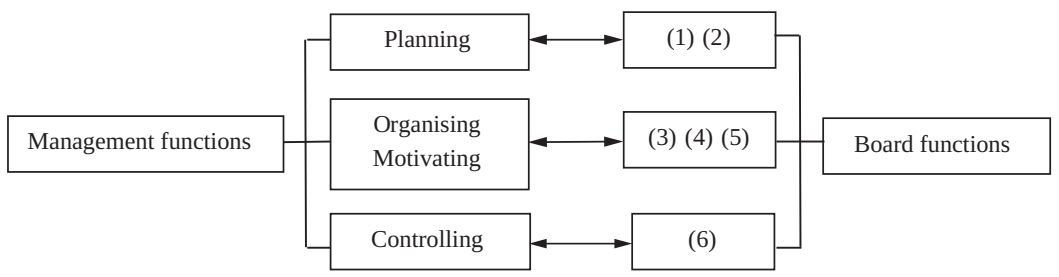

Figure 1. Management functions vs. board functions

Source: authors' own work.

Effectiveness of the management stems not so much from understanding various functions, but from board members' preparation to perform these functions. Therefore, the right person on the position of CEO and right co-workers are the key. The professionalism of board members is obviously crucial, but one must also take into account other factors which are important for the company, such as: human resources, customers, and the society in general. So, do the boards have relations (do they cooperate) with these groups?

The literature mentions management models based on different factors, such as individual leadership, active management, geographical representation and social representation (Boland and Hofstrand, 2009; Bartnicki, 2007, pp. 107-121). Each of them assumes, however, 
that depending on the situation, the attitudes of a member (members) of the board will change; for example, in case of geographical representation, the board member will carry out objectives of owners or investors who appointed them. It does not mean a common mission, or striving to achieve team goals. Therefore, this article presents a concept of a dynamic board composition, depending on current company circumstances; the board should always be focused on accomplishing the mission and goals of the entire company, not particular interests. And although there is no mandatory rule for formulating the structure of boards, it seems beneficial to companies to have a board whose members come from different groups, so that they can better understand the employees, customers and the society. Board structure should reflect these groups, at least to some extent. To illustrate the presented concept, a fictitious limited liability company was used; three board models (the purpose of the article) were developed, depending on various market situations. A company should find it easier to adapt to changing conditions when the board is aware of these changes and is a part of them; further considerations were based on this point of view. This article is organised as follows: it provides an analysis of the literature on functioning of company boards; it presents a fictional company, for which three board models were developed, depending on the company market situation; the article also discusses the advantages and limitations of each model. Finally, it presents conclusions and recommendations for further research.

\section{Review of the literature}

The board of directors (henceforth: board) is a specific link between the owners of the company and its management (Crow and Lockhart, 2016, pp. 1022-1037). In the literature, various configurations of boards are discussed, to determine the one with the best market effects (Andrews, 1980, pp. 30-42; Boone, Casares Field, Karpoff and Raheja, 2007, pp. 66-101; Huse, 2007). However, it seems that boards themselves were usually ignored in the studies, until we began to observe the fall of large companies. Insolvency of companies became a trigger for comprehensive analyses of business entities, including their boards (Crow and Lockhart, 2016, pp. 1022-1037). So far, however, no work has presented a comprehensive concept for composition, operation and fall 
of boards, therefore this discussion is still open. Lack of comprehensive knowledge stems from the fact that board activities are a social construct, i.e. they are dynamic, unique, and sometimes unpredictable. Moreover, they are closely linked to the interests of owners and stakeholders, thus, the area of interaction is very broad. Previous studies and analyses concerned mainly the issue of what boards actually do, and how their actions affect the market performance of companies (Huse, 2007, pp. 38-48). Moreover, they dealt with finding patterns and regularities in board activities, without, however, any assessment of how they affected the situation of the company, or if they were relevant at all. Some studies included statistical analyses, which served as a basis for constructing flowcharts and predicting future results. However, in practice, it is still problematic, because predicting the future based on past events is unreliable.

Most of previous studies which suggested reconstruction of boards, pointed to quantitative changes. First of all, they postulated a greater diversification in terms of participation of women; they argued that women's presence brings a positive effect for the company (Van der Walt, Ingley, Shergill and Townstend, 2006, pp. 129-147; Campbell and Miguez Vera, 2010, pp. 37-59). Companies are often pressured by stakeholders, especially activists in the field of human rights and sustainable development, but also by investors who want their boards to be diverse in terms of gender and ethnic origin. However, it seems that this pressure is quantitative in nature; it is expected that companies will seek the parity (equal participation) of women on boards. Of course, there is no denying that companies should ensure equal opportunities for women and men, but the desire to employ $50 \%$ of women does not seem right from the point of view of the effectiveness of management. Board structure, as well as human resources structure in general, must be based on logical, justified reasons.

The main problem is how to manage the diversity of human resources (including the structure of the board), as the pursuit of diversification carries a few risks: although diversified groups are more dynamic and creative, they are also more difficult to integrate, and they face conflicts more often (Van der Walt et al., 2006, pp. 129-147). Therefore, any 'human' approach to management, related to diversity, will probably have both positive and negative effects, which companies should be aware of. Ingley and Van der Walt (2003) argue, however, that with the increasing complexity of businesses, there should also be 
a growing variety of board members, as it positively affects the quality of decisions.

The relation between the complexity of the business and the diversity of the board - according to Ingley and Van der Walt - requires broader analyses, but based on a survey of companies in New Zealand, in the face of turbulent environment and changes in companies, diversified boards achieved better profitability and growth. Many other studies have stressed that functional diversity, i.e. one that spans beyond gender representation, has a positive effect on problem-solving and decision-making, as well as on the general position of the company on the market (Biggins, 1999, pp. 11-17; Hurn, 2012, pp. 126-131; Ramakrishnan, 2012, pp. 38-48; Gianluca and Keasey, 2012, pp. 272-286).

The above-mentioned issue is associated with concepts of authentic leadership and social responsibility. Authentic leader - one who creates a positive, ethical atmosphere in the company and ensures adequate conditions for its functioning - appreciates the diversity and wants to use it for the good of the company (Stankiewicz, 2010, pp. 235-239; Glińska-Neweś and Stankiewicz, 2013, pp. 17-34). Being responsible, the authentic leader pays attention to ensuring equal opportunities for employees. A diverse board, along with an authentic leader, and the concept of responsible business, may serve as an important, positive potential of the company, a source of competitive advantage (Karaszewski and Lis, 2014, pp. 1056-1062).

\section{The specificity of the limited liability company board}

According to statistical data, there are about 4,155,000 businesses in Poland; 4,017,000 of them are private entities. Among them, there are limited liability companies, partnerships, self-employed (they are the most numerous group: almost 3,000,000), as well as associations and foundations (GUS, nd).

Among companies, one may distinguish limited companies and partnerships. The first category includes limited liability companies, which may be established by one or more persons for any legal purpose (Commercial Companies Code, 2000, art. 151). To establish a limited liability company (sp. z o.o.) it is necessary to sign a company deed, bring the share capital, appoint the board, establish a supervisory board 
or an audit committee (in certain cases), as well as notify the Register of Entrepreneurs. The creation of the board is an important step in the establishment of a company; it is reported to the Register with details of names and addresses of all board members, along with definition of their roles in the company.

A board of a limited liability company may consist of one or more persons. It may include shareholders and 'outsiders', which is regulated in the company deed. Board members are appointed and dismissed by resolution of shareholders. They may be appointed for one year or another period. A board member, however, can be dismissed at any time by resolution of shareholders. The board primarily represents the company on the outside; the method of representation is usually defined in the company deed. However, if the board does not represent the company, any statement on behalf of the company may be made if at least two board members (or one member and a proxy) cooperate. Primary responsibilities of the board include running the company and representing it in civil and legal actions.

Nowadays, the composition of company boards is a result of many factors and forces. These include: the legal form of the entity, its size and the owner structure. In case of public entities, one must also keep in mind the socio-political conditions. In non-governmental organisations, their leader plays a key role. Both groups of entities - public and non-governmental - will not be considered in this study due to their uniqueness. The article will focus on a limited liability company, whose goal is making profit and increasing its market value by meeting customer needs.

\section{Characteristics of the fictitious company}

To present the model of board composition, a fictitious company will be used. It is a manufacturing and service company called Ella sp. z o.o., based in Szczecin (Poland). Since 1997, it has produced and sold garden furniture. The company was established by 10 shareholders. The company deed states in Paragraph 7 that the company bodies are: the board and the meeting of shareholders. Next paragraph specifies that the board consists of 4 persons, and their term is 4 years.

Initially, the company focused on the north-western region of Poland, and gradually expanded its operations throughout the country. 
Currently, it is planning to expand into European markets, starting with Spain, and specifically the region of Murcia. In the next $4-5$ years, the company wants to increase sales abroad to approximately $25 \%$ of the production volume. The financial situation of the company is good, which allows for business expansion plans. In 2016, the company sold the biggest production volume in West Pomeranian voivodship (45\%), while Pomeranian voivodship (30\%) came second. The remaining production volume was sold at various outlets in Poland.

Due to manufacturing nature of the company, $60 \%$ of employees are men. Currently, the company board, as mentioned above, consists of 4 people (only men), aged 50-65. At lower management levels, women constitute $30 \%$ of employees (there are 18 managers, including 6 women). As of 31 December 2016, the company employed a total of 227 persons. The structure of employees by age and gender is presented in Table 1 and Figure 2.

Table 1. Structure of human resources

\begin{tabular}{lllll}
\hline Age group & $\begin{array}{l}\text { Participation } \\
\text { in \% }\end{array}$ & Total & Women & Men \\
\hline $18-25$ & 10 & 23 & 9 & 14 \\
\hline $26-35$ & 13 & 29 & 6 & 23 \\
\hline $36-45$ & 43 & 98 & 49 & 49 \\
\hline $46-55$ & 27 & 61 & 18 & 43 \\
\hline $56-65$ & 7 & 16 & 9 & 7 \\
\hline Total & & 227 & 91 & 136 \\
\hline
\end{tabular}

Source: authors’ own work.

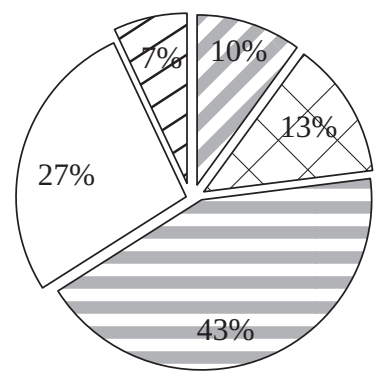

Figure 2. Structure of company employees by age

Source: authors' own work. 
The market in which the company operates is moderately competitive. There is a relatively stable growth in demand, triggered by creation of suburban housing and the tendency to settle outside the city centre. In 2015, West-Pomeranian voivodship had a population of 1,713,849 people, including $51.4 \%$ women and $48.6 \%$ men. Although the population remains at a similar level, people's wealth increased: in 2005, the average gross earnings amounted to EUR 176; in 2015, it was EUR 329.5. Furthermore, there is a constant tendency of moving from city centres to the outskirts and the countryside, which increases the demand for garden furniture. Similar trends can also be seen in other regions of Poland, which is why the company decided to expand its distribution channels by creating sales offices and investing in online sales. These initiatives may bring good results because there are many areas where unemployment is lower than in West Pomerania, and working age population is more numerous. Therefore, these regions may become potential target group for the company.

\section{Building a better board - scenarios}

Scenario 1 - The company board reflects the structure of employees and the structure of the local market

In 2016, the company board consisted of 4 persons; as mentioned before, they were all men aged 50-65. Board structure was a result of business connections and experience of the appointed board members. One member was one of the founders, while others were appointed for the first term and have acted for 10 years as the Production Executive Officer, the Financial Executive Officer, and the Development and Sales Executive Officer. If the company board was to reflect human resources, it should include three new persons aged 36-45. There should be one woman on the board, as women constitute $40 \%$ of employees (Table 2).

Changes in the board should result from market dynamics. Therefore, given the structure of population by gender and the structure of the economically active people in Western Pomerania, as well as people living in rural areas (31.4\% of the population), a different board should be appointed; that board would include one person from the group of founders (male), two men aged 36-45 (as they reflect the structure of employees), and one woman aged approximately 40. Moreover, one 
person should live in rural areas. Another solution would be to appoint three new members - this time two women and one man; thus, entire board would correspond to the structure of society in the region $(51.4 \%$ women, $48.6 \%$ men). Still, three new members should live in rural areas (Table 2).

Table 2. Suggestion of the new board - model 1

\begin{tabular}{|c|c|c|c|c|}
\hline Scenario 1 & $\begin{array}{l}\text { Number of } \\
\text { people on } \\
\text { the board }\end{array}$ & Gender & $\begin{array}{l}\text { Persons } \\
\text { - Age }\end{array}$ & $\begin{array}{l}\text { Other char- } \\
\text { acteristics }\end{array}$ \\
\hline Current board & 4 & 4 men & $50-65$ & ? \\
\hline $\begin{array}{l}\text { Board after changes } \\
\text { - ver. 1a }\end{array}$ & 4 & $\begin{array}{c}3 \text { men } \\
1 \text { woman }\end{array}$ & $\begin{array}{c}1-50-65 * \\
2-36-45 \\
1-36-45 \\
\end{array}$ & $\begin{array}{c}1 \text { person } \\
\text { from rural } \\
\text { areas }\end{array}$ \\
\hline $\begin{array}{l}\text { Board after changes } \\
\text { - ver. 1b }\end{array}$ & 4 & $\begin{array}{c}2 \text { men } \\
2 \text { women }\end{array}$ & $\begin{array}{c}1-50-65 * \\
1-36-45 \\
2-36-45\end{array}$ & $\begin{array}{l}1 \text { person } \\
\text { from rural } \\
\text { areas }\end{array}$ \\
\hline
\end{tabular}

* one of the founders

Source: authors' own work.

Scenario 2 - The company board reflects the structure of employees and the structure of the national market

If the company is growing, board growth seems to be a logical consequence. This should be understood as a transition to a more complex form - perfected in some ways. In this case, the company decided to expand its business onto the domestic market. This means not only organisational changes within the company, but also a different customer structure. Assuming that such changes take place, the company should adapt the board accordingly. Given unchanged human resources and modified market realities, the company should maintain the structure of the members in terms of age and gender, but should think about the structure of their customers (current and potential). The company should also consider new segmentation of the market, taking into account the percentage of population living in rural areas, the average income in different regions of the country, the number of people with disabilities, and number of immigrants, as these factors determine the domestic market. 
It is worth noting that in 2015, over 121,000 people arrived to Poland in search of permanent residence. Therefore - given the latter factor - the company should be prepared that its employees, and perhaps customers, might include citizens of Ukraine (31\% of all foreigners with residency permit). In Poland, there are approximately $6,000,000$ disabled people. Could they become employees of the company? To what extent? If so, the company board should reflect these changes, too. One suggestion would be to add another woman to the board (this means modification of the company deed, which mentions only 4 members); it has been proven that feminine management style is focused on good relationships within the company, and customer satisfaction (Hernik and Minguez Vera, 2016, pp. 57-63). This will be important in the face of expansion and the need to reconcile different interests, and solve problems. What is more, women often act as decision-makers about furniture purchases, so the board would reflect the market situation more faithfully. Board structure for the domestic market is presented in Table 3.

Table 3. Suggestion of the new board - model 2

\begin{tabular}{lcccl}
\hline Scenario 2 & $\begin{array}{c}\text { Number of } \\
\text { people on } \\
\text { the board }\end{array}$ & Gender & Age & $\begin{array}{l}\text { Other } \\
\text { characteristics }\end{array}$ \\
\hline Current board & 4 & 4 men & $50-65$ & ? \\
\hline & 2 men & $\begin{array}{c}1-50-65^{*} \\
1-36-45\end{array}$ & $\begin{array}{l}1 \text { person from rural areas; } \\
\text { optionally: } \\
\text { a person familiar with the reali- } \\
\text { ties of life of disabled people; } \\
\text { changes - ver. 2 }\end{array}$ \\
& 5 & 3 & $\begin{array}{l}2-36-45 \\
\text { a person with experience on } \\
\text { the Ukrainian market }\end{array}$ \\
\hline
\end{tabular}

Source: authors’ own work.

Scenario 3 - The company board reflects the structure of employees and the structure of the international market

The company, as mentioned before, wants to expand on the international market, starting from the Spanish region of Murcia. Murcia was chosen due to sparse native competition, and the lack of good raw materials in the area of south-eastern Spain; therefore, furniture from Poland should 
find buyers easily. The city of Murcia, in terms of population, gender and average age of residents is similar to Szczecin (INE, nd), while the whole region of Murcia is similar to the West Pomeranian voivodship. An important difference is the number of immigrants: in 2015, in the province of Murcia there were 208,355 foreigners with permanent residence, while in West Pomeranian voivodship - approximately 700 individuals. Similarities and differences between the provinces are shown in Table 4.

Table 4. Selected elements of the market, affecting the operations of the company

\begin{tabular}{|c|c|c|c|c|c|c|c|c|c|c|}
\hline & 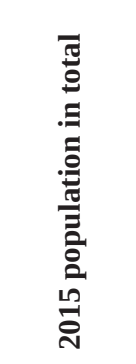 & $\begin{array}{l}\overline{d^{0}} \\
\vdots \\
\vdots \\
\vdots \\
\vdots\end{array}$ & $\frac{\sqrt{\circ}}{\text { J }}$ & 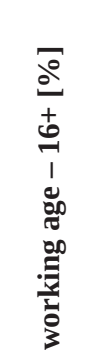 & 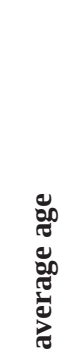 & 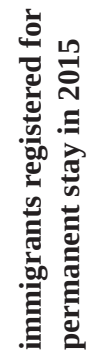 & 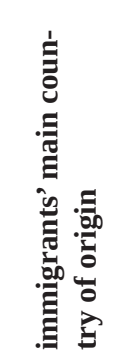 & 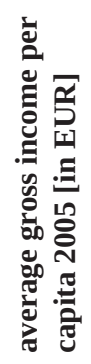 & 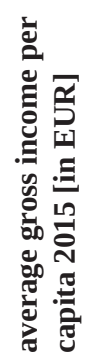 & 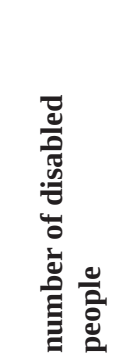 \\
\hline $\begin{array}{l}\text { West } \\
\text { Pomerania }\end{array}$ & $1,713,849$ & 51.40 & 48.60 & 43.40 & 40.3 & $691 *$ & Germany & 176 & 329 & 233,500 \\
\hline $\begin{array}{l}\text { Murcia } \\
\text { Province }\end{array}$ & $1,466,507$ & 49.87 & 50.13 & 59.45 & 39.6 & 208,355 & Morocco & 1,443 & 1,577 & 217,324 \\
\hline \multicolumn{11}{|c|}{ * Data from 2014} \\
\hline
\end{tabular}

Upon start of operations in Murcia, the company may be pleasantly surprised by the average monthly income, which is five times higher than in West Pomerania. This could mean greater purchasing power of an average family. However, it should be noted that the family is likely to have different expectations (different style of leisure) and may come from Morocco or another Spanish-speaking country, because - as shown in Table 4 - the number of immigrants in Murcia is many times greater than in West Pomerania.

For the expansion on the Spanish market, the company should modify its board structure by including a $6^{\text {th }}$ member (who could act 
as a European Market Development Director). The population structure in Murcia shows equal participation of women and men, and the average age is approximately 40 years; there is also a similar number of people with disabilities, therefore the current board generally corresponds to these proportions. However, due to the distinctive nature of the Spanish market, the board would need another person. It should be a man because firstly, previously the board was supplemented by a woman, and secondly, men continue to constitute majority of the crew. The new person, apart from professional experience, should be familiar with the Spanish language and culture, as well as the culture of the North African countries (Table 5). Planning further expansion in Spain, the board should keep in mind that although the average monthly income is 1,941 EUR, many regions face high unemployment rate (Eurostat, 2017).

Table 5. Suggestion of the new board - model 3, considering the Spanish market

\begin{tabular}{|c|c|c|c|c|}
\hline Scenario 3 & $\begin{array}{l}\text { Number of } \\
\text { people on } \\
\text { the board }\end{array}$ & Gender & Age & Other characteristics \\
\hline $\begin{array}{l}\text { Previous } \\
\text { model } 2\end{array}$ & 5 & 2 men & $\begin{array}{c}1-50-65^{*} \\
1-36-45 \\
2-36-45 \\
1-46-55\end{array}$ & $\begin{array}{l}1 \text { person from rural areas; } \\
\text { a person familiar with the realities of } \\
\text { life of disabled people; a person with } \\
\text { experience on the Ukrainian market }\end{array}$ \\
\hline $\begin{array}{l}\text { Model } 3 \text { for } \\
\text { the Spanish } \\
\text { market }\end{array}$ & 6 & $\begin{array}{l}3 \text { men } \\
3 \text { women }\end{array}$ & $\begin{array}{c}1-50-65^{*} \\
2-36-45 \\
2-36-45 \\
1-46-55\end{array}$ & $\begin{array}{l}1 \text { person from rural areas; } \\
\text { a person familiar with the realities of } \\
\text { life of disabled people; a person with } \\
\text { experience on the Ukrainian market; } \\
\text { a person familiar with the Spanish } \\
\text { language and culture, plus familiar } \\
\text { with the culture of North African } \\
\text { countries }\end{array}$ \\
\hline
\end{tabular}

Source: authors' own work.

Planning further expansion on the Spanish market, the company should compare the parameters of the Polish and Spanish markets, and think about whether the differences are significant enough to modify the board, or perhaps even the organisational structure of the company. It seems that currently there are no significant differences (Table 6), 
and therefore the board could function according to the model 3 on the Spanish market.

Table 6. Selected elements of the Polish and Spanish market, affecting the operations of the company

\begin{tabular}{|c|c|c|c|c|c|c|c|c|}
\hline & 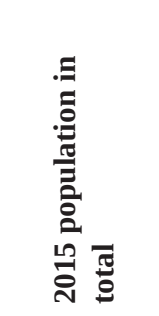 & 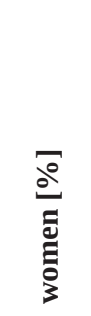 & $\frac{\bar{d}}{\bar{d}}$ & 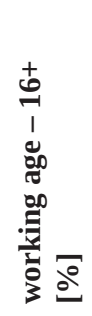 & 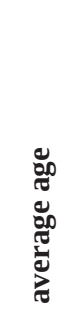 & 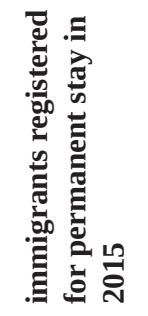 & 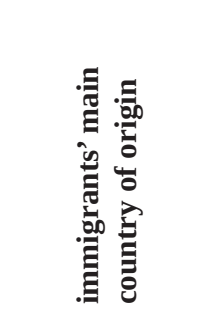 & 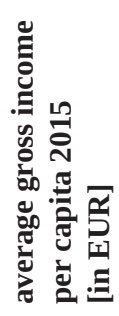 \\
\hline Poland & $38,426,809$ & 51.60 & 48.40 & 62.40 & 40.9 & 121,219 & Ukraine (31\%) & 958 \\
\hline Spain & $46,445,828$ & 50.89 & 49.11 & 59.54 & 42.7 & $4,418,157$ & Romania (15\%) & 1,941 \\
\hline
\end{tabular}

Source: http://countrymeters.info/en/Spain (accessed 10 February 2017), and http://stat.gov.pl/ obszary-tematyczne/ludnosc/ (accessed 07 February 2017).

\section{Discussion}

The company board, as mentioned before, represents the interests of the owners, so its actions are monitored by owners (Crow and Lockhart, 2016, pp. 1024). It turns out, however, that the owners' supervision is inadequate in terms of effective management, and many companies experience difficulties. These difficulties result from insufficient information, inadequate implementation of strategies, fraudulent actions and other illegal activities, as well as the lack of codes of practice.

It must be stated that every board is a complex organ and needs to be analysed in the context of various factors, such as the specifics of the company, its stakeholders, customers and owners (Tricker and Tricker, 2012, pp. 67-72). All of these elements determine board's activity. According to Crow and Lockhart, boards are social constructions, so it is logical to consider their activities in terms of interaction with different groups of stakeholders. As previously mentioned, the literature attempted to construct certain patterns of behaviour and predict future results of board operations; unfortunately, predicting future based on past events is unreliable, therefore, the issue of the right board model 
is still open for discussion. One may agree, however, that every board should have certain competences (Godziszewski, 2010, pp. 17-36), and should make decisions after considering all available data, analyses and opinions. It would be beneficial to the company to have a board which reflects the characteristics of human resources, suppliers, customers and the society, because then it may better understand behaviours of stakeholder groups and better identify risks and take advantage of various opportunities. It seems unlikely that this could be accomplished by the 4-person board composed of men only, appointed to the board 10 years earlier, based on their relationship with the founders and their professional experience. Such factors do not ensure the success of a company; or rather, the success may be attributed to other factors than board actions. In other words, the board should be constructed with more holistic factors in mind.

The method of appointing the company board, as mentioned before, depends on many determinants (Biggins, 1999, pp. 11-17; Gianluca and Keasey, 2012, pp. 272-286). It seems, however, that currently individual characteristics of candidates seem dominant (especially professional experience); sometimes personal relations play a role; staff structure is not considered at all (even though the board manages people), nor the structure of society (or to be more precise: the market) in spite of the fact that the board should understand market expectations and implement strategy built on these expectations. In practice, there are few companies (entities) which use certain principles when appointing boards. These include state-owned enterprises and non-governmental organisations. The former should use good practice for state-own enterprises when appointing their boards. Thus, a board member must have full legal capacity to act and have full civil rights; they should have completed proper education and have relevant professional experience; they should not be employed by political parties or be active in their structures; they must not be employed in senators or MP's offices. These guidelines, however, apply only to public entities. As for associations and foundations, their method of appointing boards is determined by their charter; elections are held among the members, so the question of involving a particular person is more important than their professional experience or personal relationships. In private companies, the composition and characteristics of boards are decided by owners. They may take any approach, as long as it is not contrary to the company deed / articles of association. 
The effectiveness of the board may be assessed on the basis of financial results of the company (e.g. return on sales, return on equity, cost level indicator), but also by evaluating the market position of the company: its competitiveness, optimization of resources and organisational structure. The question of competitive advantage may be of particular importance, because a company which wants to appoint its board dynamically will have a different approach from its competitors; it may also respond to changes on the market better (with more flexibility), which may bring positive effects (Hernik, 2014, pp. 39-47).

In practice, one may encounter strategies of expanding boards (or hiring executive directors) with members from other countries when the company plans international expansion. This is particularly important for companies from different cultures, e.g. when a Japanese company wants to sell its products in the US (Genestre, Herbig and Shao, 1995, pp. 16-27). The Japanese not only alter structure of their boards, but also analyse markets carefully and look for niches missed by domestic companies. Discovering such niches is easier with the support of a person (persons) who knows the market, consumers, legal realities, etc.

A board created according to the proposed guidelines will have several advantages: it will have a more diverse approach to company operations, which means a more comprehensive and diversified input; it will need to take into consideration more diverse ideas and preferences, thus avoiding short-sightedness and constraints in implementation of strategies; it will also be more flexible and willing to implement innovative solutions. The board will be also willing to create strategies which take into account a wider group of stakeholders: not only employers, but also employees (Haffer, 2010, pp. 202-214).

In addition, a diverse board will do better in terms of social interactions - commitment and empathy will be needed to create a new strategy and to negotiate goals (communication), to control, and to implement adjustments and changes. So far, boards have taken bad decisions, or have not taken them at all, because they were too homogenous and conservative; as a result, they had limited access to information; they were also limited by routine and excessive confidence in professionalism. The proposed models may solve the presented problems to some extent.

It has been proposed that - regardless of the company size and its customers - the company board should always reflect the structure of employees and customers. In case of extensive operations, certain simplifications are necessary, but it seems that establishing the 
board composition only on the criterion of professionalism may be short-sighted. This is proved by difficulties and bankruptcies of many companies. Therefore, a dynamic composition of the board may be the right solution; such a board would have adequate experience as well as skills and knowledge that go beyond professional preparation (Ingley and Van der Walt, 2003).

Difficulties which may arise with this approach are associated with the need to integrate new persons into the board. Each time it will take time, so it is very important that all board members understand and support this initiative of change. Less involvement of board members - or even conflicts - are possible, if the owners accept the dynamic composition of the board but decide to keep the current size of the board (i.e. the new person would replace the current board member). Finally, legal restrictions also pose a risk, as currently job advertisements must give equal opportunities to women and men, while in our model, the company needs a female board member. It seems, however, that a clear and reasonable strategy to appoint the board may help avoid accusations of discrimination, so that legal issues may be prevented. Additionally, it is important - according to Haffer (2010) - that companies have transparent and consistent procedures for hiring. The presented ideas may complement such procedures.

\section{Conclusions}

As stated before, the method of appointing company boards depends on many determinants. Currently, individual characteristics of candidates are given the most importance; sometimes personal relations are also taken into account; human resources structure, however, is not considered (and yet, the board manages people), society structure also tends to get ignored, despite the fact that the board should know society's expectations to build and implement strategy based on these expectations. In private companies, the composition and characteristics of the board are decided by owners. They may take any approach, as long as it is not contrary to the company deed / articles of association. In this article, we developed a model for appointing company boards. It assumes that - apart from a representative of the owners - the board structure should include members who reflect the structure of the employees and/ or the structure of customers. Moreover, the board structure should be 
modified to follow the changing conditions of the company, especially when expanding the market. Depending on the situation, the board should include persons of particular gender, education, and knowledge that goes beyond management capacity. In our view, a structure based on gender parity or professionalism is not satisfactory. The advantage of dynamic board composition is lack of routine, flexibility, and rapid adaptation to change and innovation. Among potential problems, we may include slow integration of the new board member with current members, conflicts, and legal restrictions on employing new members; therefore, this model should be carefully planned and implemented with the approval of board members and managers, so as to avoid accusation of discrimination. It seems, however, that the board composition method we have presented may be compatible with the authentic leadership philosophy and ideas for building competitive advantage.

\section{References}

Andrews, K.R. (1980), “Directors’ Responsibility for Corporate Strategy”, Harvard Business Review, Vol. 58, No. 6, pp. 30-42.

Bartnicki, M. (2007), “Dynamizowanie procesu zarządzania: Organizacyjny pierwowzór przedsiębiorczości”, in: Henzel, H. (Ed.), Dynamika zarzq̨dzania organizacjami: Paradygmaty - metody - zastosowania, AE, Katowice.

Biggins, J.V. (1999), “Making Board Diversity Work”, Corporate Board, Vol. 20, No. 117, pp. 11-17.

Boland, M., Hofstrand, D. (2009), "Business Strategy and the Board of Directors”, Ag Decision Maker, Iowa State University. Retrieved from www.extension.iastate.edu/ agdm (accesed 4 February 2017).

Boone, A.L., Casares Field, L., Karpoff, J.M., Raheja, C.G. (2007), “The Determinants of Corporate Board Size and Composition: An Empirical Analysis”, Journal of Financial Economics, Vol. 85, No. 1, pp. 66-101.

Campbell, K., Minguez Vera, A. (2010), "Female Board Appointments and Firm Valuation: Short and Long-term Effects”, Journal of Management and Governance, Vol. 14, pp. 37-59.

Commercial Companies Code (2000), Kodeks spółek handlowych, Dz.U. 2017.1577.

Crow, P.R., Lockhart, J.C. (2016), "How Boards Influence Business Performance: Developing an Explanation”, Journal of Leadership \& Organization Development, Vol. 37, No. 8, pp. 1022-1037.

Dołhasz, M., Fudaliński, J., Kosala, M., Smutek, H. (2009), Podstawy zarzq̨dzania: Koncepcje - strategie - zastosowania, PWN, Warszawa.

Eurostat (2017), “Unemployment Statistics”. Retrieved from http://ec.europa.eu/ eurostat/statistics-explained/index.php/Unemployment_statistics (accessed 13 February 2017).

Genestre, A., Herbig, P., Shao, A.T. (1995), "What Does Marketing Really Mean to the Japanese?”, Marketing Intelligence \& Planning, Vol. 13, Issue 9, pp. 16-27. 
Gianluca, V., Keasey, K. (2012), “A (New) Model of Board of Directors: Evidence from the National Health Service”, International Journal of Public Sector Management, Vol. 25, Issue 4, pp. 272-286.

Glińska-Neweś, A., Stankiewicz, M.J. (2013), “Key Areas of Positive Organisational Potential as Accelerators of Pro-developmental Employee Behaviours", in: Stankiewicz, M.J. (Ed.), Positive Management: Managing the Key Areas of Positive Organisational Potential for Company Success, Dom Organizatora TNOiK, Toruń, pp. 17-34.

Godziszewski, B. (2010), “Zasobowe uwarunkowania rozwoju przedsiębiorstwa”, in: Stankiewicz, M.J. (Ed.), Pozytywny Potencjał Organizacji: Wstęp do użytecznej teorii zarzq̨dzania, Dom Organizatora TNOiK, Toruń, pp. 17-36.

GUS (nd), “Liczba podmiotów w rejestrze REGON (tablice)”. Retrieved from http:// bip.stat.gov.pl/dzialalnosc-statystyki-publicznej/rejestr-regon/liczba-podmiotoww-rejestrze-regon-tablice/ (accessed 09 February 2017).

Haffer, R. (2010), "Relacje pomiędzy komponentami modelu wewnątrzorganizacyjnych oddziaływań Pozytywnego Potencjału Organizacji”, in: Stankiewicz, M.J. (Ed.), Pozytywny Potencjał Organizacji: Wstęp do użytecznej teorii zarzq̨dzania, Dom Organizatora TNOiK, Toruń, pp. 159-213.

Hernik, J. (2014), "Diversity as an Innovative Model of Business”, Cross Cultural Business Conference 2014: Proceedings, Shaker Verlag, pp. 39-47.

Hernik, J., Minguez Vera, A. (2016), "Women on Managing Boards - Are Companies More Responsible when Women Share the Power?”, Organisational Studies and Innovation Review, Vol. 2, Issue 4, pp. 57-63.

Hurn, J.B. (2012), “Removing the Boardroom Glass Ceiling”, Industrial and Commercial Training, Vol. 44, Issue 3, pp. 126-131.

Huse, M. (2007), Boards, Governance and Value Creation, Cambridge University Press, Cambridge.

INE (nd). Retrieved from http://www.ine.es/ (accessed 13 February 2017).

Ingley, C.B., Van der Walt, N.T. (2003), “Board Configuration: Building Better Boards”, Corporate Governance: The International Journal of Business in Society, Vol. 3, No. 4, pp. 5-17.

Karaszewski, R., Lis, A. (2014), “Przywództwo i CSR w kontekście pozytywnego potencjału organizacji”, Marketing i Rynek, No. 5, pp. 1056-1062.

Murcia (nd), “El Padrón Municipal de Habitantes”. Retrieved fromhttp://www.murcia. es/web/portal/el-padron-municipal-de-habitantes (accessed 10 February 2017).

Pomorze Zachodnie (nd), “Stan i struktura ludności”. Retrieved from http://eregion. wzp.pl/obszary/stan-i-struktura-ludnosci (accessed 07 February 2017].

Ramakrishnan, V. (2012), "High Performing Boards: Going Beyond Compliance”, Journal of Business Strategy, Vol. 33, Issue 2, pp. 38-48.

Stankiewicz, M.J. (2010), “Uwarunkowania Pozytywnego Potencjału Organizacji zarys modelu kształtowania PPO w przedsiębiorstwie”, in: Stankiewicz, (Ed.), Pozytywny Potencjał Organizacji: Wstęp do użytecznej teorii zarzqdzania, Dom Organizatora TNOiK, Toruń, pp. 215-239.

Sudoł, S. (2007), Nauki o zarzq̨dzaniu: Węzłowe problemy i kontrowersje, Dom Organizatora TNOiK, Toruń.

Tricker, B., Tricker, R. (2012), Corporate Governance: Principles, Policies and Practices, Oxford University Press, Oxford. 
UStat (2015), Ludność, ruch naturalny i migracje w województwie zachodniopomorskim w 2014 roku, Urząd Statystyczny w Szczecinie, Szczecin. Retrieved from http://eregion.wzp.pl/sites/default/files/ludnosc_ruch_naturalny_2014_z.pdf (accessed 07 February 2017).

Van der Walt, N., Ingley, C., Shergill, S.G., Townstend, A. (2006), "Board Configuration: Are Diverse Boards Better Boards?”, Corporate Governance: The International Journal of Business in Society, Vol. 6, No. 2, pp. 129-147. 